Proc. Estonian Acad. Sci. Geol., 1994, 43, 4, 183-191

\title{
CONODONTS FROM THE PUSKU QUARRY, LOWER LLANDOVERY, ESTONIA
}

\author{
Peep MANNIK
}

Eesti Teaduste Akadeemia Geoloogia Instituut (Institute of Geology, Estonian Academy of Sciences), Estonia pst. 7, EE-0100 Tallinn, Eesti (Estonia)

Presented by D. Kaljo

Received April 5, 1994; accepted May 20, 1994

Abstract. Ozarkodina excavata puskuensis subsp. n., a new representative of $O$. excavata with wide, closely spaced, partially fused denticles is described from the Pusku section (western Estonia). A short general paleontological and lithological characterization of the studied section is given.

Key words: conodonts, paleontology, stratigraphy, Early Silurian, Estonia.

Conodonts are poorly known from the Rhuddanian and Aeronian in Estonia, due to their rare occurrence. Only extensive processing of samples during the last years has enabled to indicate quite a diverse conodont fauna from this interval, particularly from the Raikküla Formation (Männik \& Viira, 1990; Männik, 1992). One of the most productive sections in the last stratigraphic interval appeared to be the Pusku Quarry, located in western Estonia and probably representing the upper part of the Rhuddanian (Figs. 1, 2). From this section, sampled repeatedly during several years, numerous new undescribed taxa were identified together with the well-known conodonts. This paper gives general information on the Pusku section and a description of a new subspecies of Ozarkodina excavata (Pls. I and II).

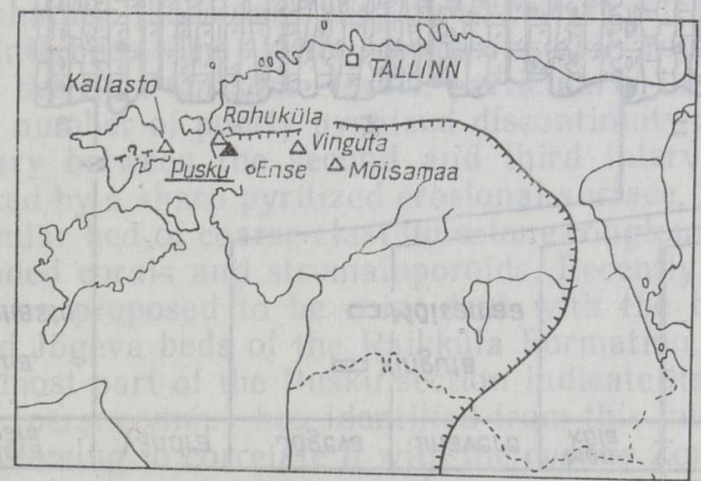

$\triangle$ Pusku Quarry, other outcrops, o core

Fig. 1. Location of the studied and mentioned sections. The indented line indicates the contour of the distribution area of the Raikküla Stage. 

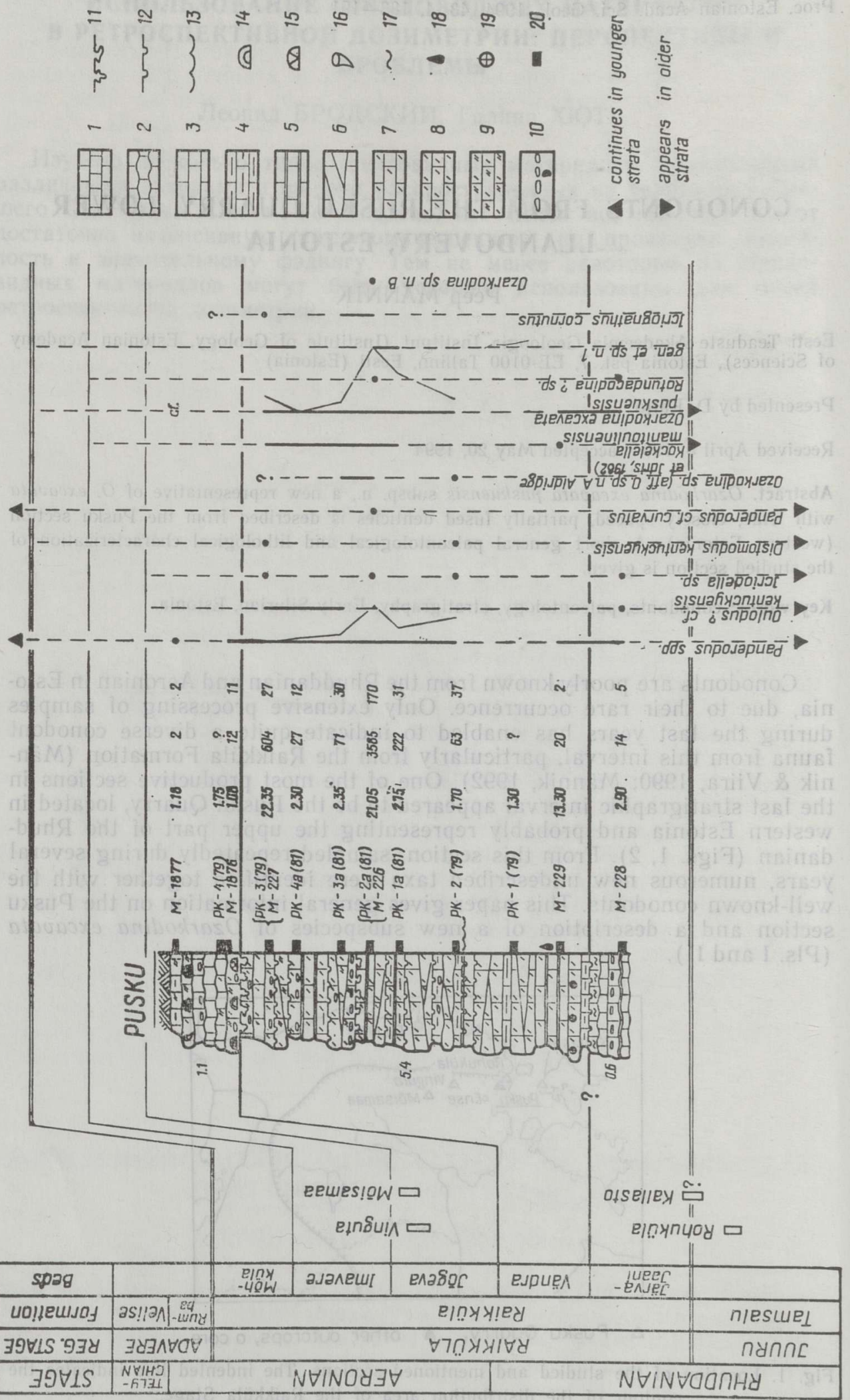
Fig. 2. Distribution of conodonts in the Pusku Quarry section. The location and number of the studied samples, the weight of the samples in $\mathrm{kg}$, the number of conodont specimens in the samples, and the number of conodont specimens per $1 \mathrm{~kg}$ of rock are given at the right of the log.

1, aphanitic limestone; 2 , nodular aphanitic limestone; 3 , micritic limestone; 4, argillaceous limestone; 5 , limestone with interbeds of marlstone; 6 , cross-bedding structures; 7, fine-grained detritic limestones; 8 , fine-grained detrital limestones; 9 , unsorted fine- to coarse-grained detrital limestones; 10 , conglomerate; 11 , erosional surface; 12 , discontinuity surface; 13 , ripple marks; 14 , stromatoporoids; 15 , tabulate corals; 16 , rugose corals; 17 , burrows; 18 , bitumen; 19 , silicification; 20 , samples.

\section{NOTES ON LITHOLOGY}

The Pusku section, with a total thickness of $7.1 \mathrm{~m}$, is situated in an old, partially exploited limestone quarry. Lithologically the exposed interval may be divided into three main parts (Fig. 2).

1. The lowermost part (about $0.6 \mathrm{~m}$ ) of the section is represented by wave-bedded to fine-nodular aphanitic limestones with thin interbeds of calcareous marls and with conglomerates in its middle part. The upper boundary of this interval is marked by a pyritized discontinuity surface which, based on the cyclostratigraphic data, probably corresponds to the boundary between the Järva-Jaani and Vändra beds of the Raikküla Formation (Einasto \& Männik, 1991; Fig. 2).

2. The main portion of the section (about $5.4 \mathrm{~m}$ ) is made up of thickbedded, well-sorted, fine- to coarse-grained dolomitic limestones with numerous lenticular interbeds of conglomerates in its middle an upper parts. Many intervals are characterized by cross-bedding. Levels with ripplemarks and a number of erosional surfaces have been identified, particularly in the middle and upper parts of this interval.

In the Matsuküla section (about $1 \mathrm{~km}$ to SSE from the Pusku Quarry) a graptolite Paraclimacograptus estonus (Schmidt) has been identified from an interval corresponding to the second part of the studied section (Кальо, 1967).

3. The uppermost $1.1 \mathrm{~m}$ in the described section is represented by fine-nodular aphanitic limestones with rare skeletal detritus and lenticular conglomerate interbeds. The latter contain small rounded corals and coarse skeletal detritus. On some levels, particularly in the lower part of this interval, a number of poorly pyritized discontinuity surfaces occur.

The boundary between the second and third intervals of the Pusku section is marked by a sharp pyritized erosional surface, immediately overlaid by a lenticular bed of coarse-clast limestone conglomerates, containing numerous rounded corals and stromatoporoids. Recently (Einasto \& Männik, 1991) it was proposed to be coincident with the boundary between the Vändra and Jõgeva beds of the Raikküla Formation. The chitinozoans from the uppermost part of the Pusku section indicate its late Rhuddanian age. V. Nestor (pers. comm.) has identified from this interval Conochitina electa Nestor allowing to correlate it with the cyphus Zone (Нестор, 1980).

The structure and composition of the rocks refer to shallow-water high-energy conditions of sedimentation for the middle part and more variable (alternating low- and high-energy) conditions for the lower and upper parts of the Pusku section. 


\section{CONODONTS}

The rather well preserved conodont specimens are amber in colour $(\mathrm{CAI}=1)$. Most of them have a secondary, mainly crystalline coating in the Pusku Quarry section as well as in other sections of the RhuddanianAeronian age in Estonia (Pl. II, figs. 11, 13; Pl. III, fig. 5; Pl. IV, figs. $10,11,20 ; \mathrm{P} 1 . \mathrm{V} ; \mathrm{P} 1 . \mathrm{VI})$. On some specimens the denticles have totally turned into six-faced crystals (Pl. IV, fig. 20; Pl. V, figs. 4, 5; Pl. VI, fig. 6). The primary surface of the conodont specimens may be visible through some holes in the coating (Pl. V, figs. $1,2,5,6$; Pl. VI, figs. $1-5)$. These angular holes were probably made by the dolomite crystals that were in contact with the conodont surface during the time the coating was formed.

Conodonts are rare in the lower (Järva-Jaani Beds) and the uppermost (aphanitic limestones) parts of the Pusku section but more frequent in the fine- to coarse-grained dolomitic limestones of its main part.

Ozarkodina excavata puskuensis subsp. n. and Panderodus spp. are the most common taxa (Fig. 2) in this section. The former, appearing in large numbers in the lowermost part of the Raikküla Formation (Männik \& Viira, 1990), is represented by very rare specimens also in the uppermost part of the lower-lying Tamsalu Formation. Characteristic of the Raikküla Formation in Estonia, particularly of its lower part, are also Kockelella manitoulinensis (Pollock, Rexroad et Nicoll; Pl. IV, figs. 2, $4,6,7,9,13,18)$, Oulodus? cf. kentuckyensis (Branson et Branson) (Pl. III, figs. $1,2,5,6,10,11)$, and rare specimens of Icriodella sp.

Icriognathus cornutus Männik (P1. IV, figs. $10-12,14-17,19,20$ ) is so far known only from the lower part of the Raikküla Formation (Männik, 1992).

Another new yet undescribed conodont taxon is named here as Gen. et sp. n. 1 (Pl. III, figs. 3, 4, 7-9). Although the larger and robust elements of this species appear in the basal beds of the Raikküla Formation, they become more widely distributed and better preserved (Pl. III, figs. 4,8 ) in younger strata, particularly in lagoonal (?) sediments of the uppermost part of the Jõgeva Beds in Mõisamaa section (Fig. 2).

Ozarkodina sp. $\mathrm{n}$. B is represented only by a single specimen in the Pusku section (P1. IV, figs. 5, 8). Another specimen, quite similar to this one, was found from the Järva-Jaani Beds in the Ense core (at a depth of $26.5 \mathrm{~m}$ ), drilled about $25 \mathrm{~km}$ SEE from the Pusku Quarry (Fig. 1).

It is noteworthy that a conodont fauna similar to that described from the Pusku section appears in the middle part of the Kallasto section in Hiiumaa. This section as well as the overlying bioherms and coarsegrained calcarenites of the Hilliste Member is up to now considered to belong to the Juuru Regional Stage (Аалоэ \& Нестор, 1977). The conodont data seem to indicate a younger age for these strata.

The components of the conodont fauna described above are common in several regions of the world. Conodonts resembling the elements of $O$. excavata puskuensis and $K$. manitoulinensis were described from the lower Silurian of the northern Peninsula of Michigan and Ontario (Pollock et al., 1970). Aphelognathus siluricus s. f. Pollock, Rexroad et Nicoll (1970: Pl. 114, figs. $1-4)$, concurrent with these taxa, is almost identical to the modified $\mathrm{Pa}$ elements of $I$. cornutus from the Raikküla Formation (Männik, 1992).

K. manitoulinensis is also known from the Aeronian of Welsh Borderland (Aldridge, 1972) and northern Greenland (Armstrong, 1990).

Conodonts similar to Gen. et sp. n. 1 have been identified from the Brassfield Limestones in North America (R. J. Aldridge, pers. comm.). 


\section{SYSTEMATIC PART}

Ozarkodina excavata (Branson et Mehl) is one of the most common and variable species among the Silurian-Devonian conodonts. As a rule, it appears in the uppermost Llandovery but becomes more abundant in younger strata (Walliser, 1964; Aldridge, 1972, 1975).

In several sections conodonts that are quite similar to 0 . excavata have also been described from the older strata (Pollock et al., 1970; Cooper, 1975). They have more compressed blades and more fused denticles than the typical elements of 0 . excavata, and are considered to be its ancestors although no connecting links between these types have been found (Cooper, 1975).

In the Raikküla Formation of Estonia conodonts of $O$. excavata-type (see above), partly resembling those described by Cooper (1975) as $O$. protexcavata, are the most common.

The described material is deposited at the Institute of Geology of the Estonian Academy of Sciences.

\section{Ozarkodina excavata puskuensis subsp. n. \\ Plate I, figs. $1-10$ \\ Plate II, figs. $1-13$}

1970 Ozarkodina sp. n. A s. f.; Pollock, Rexroad and Nicoll, p. 757, Pl. 113, figs. $5-8(\mathrm{~Pa})$.

1970 Ozarkodina sp. n. B s. f.; Pollock, Rexroad and Nicoll, p. 757, Pl. 113, figs. 9-11 (Pa).

1970 Ligonodina? variabilis Nicoll et Rexroad s. f.; Pollock, Rexroad and Nicoll, p. 755, Pl. 114, fig. $12(\mathrm{~Pb})$.

Derivation of name: puskuensis refers to the Pusku Quarry (western Estonia), abounding in the elements of O.e. puskuensis.

Holotype. Pa element Cn 5231, Pl. I, figs. 2, 4, Pusku Quarry, late Rhuddanian.

Diagnosis. An Ozarkodina excavata-type apparatus composed of elements with wide, tall, closely spaced partially fused denticles.

Description. The $\mathrm{Pa}$ element (Pl. I, figs. 2, 4, 6-10) has a straight (juveniles) or angularly arched (adults) blade, which is commonly thickened below the denticle row. The laterally compressed denticles are the highest on the anterior blade. The cusp is poorly developed. The moderate basal cavity is the widest beneath the cusp where it flares to the concave side of the element. The cavity continues as a narrow groove on the aboral surfaces of the blades.

The $\mathrm{Pa}$ element of $O$. e. puskuensis is very similar to those described as Ozarkodina sp. n. A s. f. and Ozarkodina sp. n. B s. f. by Pollock et al. (1970, p. 757, P1. 113, figs. 5-11). Supposedly, the differences between these two formal taxa could be explained by the intraspecific variation.

The angularly arched blade of the $\mathrm{Pa}$ element in $O$. e. puskuensis resembles the one usually occupying the $\mathrm{Pb}$ position in the Ozarkodina apparatus. It is noteworthy that the studied material has yielded only the dextral (?) $\mathrm{Pa}$ elements. All the studied specimens are bent to the same side (P1. I, figs. $4,8,9$ ).

The $\mathbf{P b}$ element (Pl. I, figs. $1,3,5)$ has an angularly arched blade with processes of unequal size. The laterally compressed and inwardly 
curved denticles are the highest and most closely spaced on the anterior blade. On the posterior blade the denticles are discrete and separated by U-shaped gaps, which are wider on the juvenile specimens (Pl. I, fig. 3). Beneath the tall posteriorly inclined cusp there is a shallow laterally expanded basal cavity with poorly developed lips.

The $\mathbf{M}$ element (Pl. II, figs. 1-4) has a tall inwardly curved cusp with sharp anterior and posterior edges. The long posterior process bears inwardly curved laterally compressed denticles, which are more widely spaced on the juvenile (Pl. II, figs. 1, 2, 4) than on the adult (Pl. II, fig. 3) specimens. A short poorly developed anterior process is directed outwards and downwards, and bears one or two small closely spaced denticles. The basal cavity is the widest and deepest beneath the cusp.

The Sc element (Pl. II, figs. $5,9,12)$ has a tall posteriorly and inwardly curved cusp. The edges of the cusp are sharp. The anterolateral process is bent downwards and, in a varying degree, inwards. The posterior process is long and curved slightly downwards. The slightly laterally compressed denticles on the processes have sharp edges and are spaced widely (on juvenile specimens, Pl. II, fig. 5) or quite closely (on larger specimens, P1. II, fig. 9). A small basal cavity is situated under the cusp and extends as a narrow groove up to the ends of the processes.

\section{PLATE I}

All figured specimens are from the Pusku section; magnification $\times 100$.

Figs. 1-10. Ozarkodina excavata puskuensis subsp. n. Figs. 1, 3, 5-Pb element: 1 , 3-aboral and inner lateral views, Cn 5340, sample M-226; 5-inner lateral view, Cn 5337, sample M-226. Figs. 2, 4, 6-10-Pa element: 2, 4-lateral and aboral views, Cn 5231, sample $M-226 ; 6$-lateral view, Cn 5324, sample $M-226 ; 7,9$-lateral and aboral views, Cn 5331, sample $M-226$; 8-lateral view, Cn 5237, sample $M-226 ; 10$ lateral view, Cn 5246, sample Pk-1a(81).

\section{PLATE II}

All figured specimens are from the Pusku section; magnification $\times 100$.

Figs. 1-13, Ozarkodina excavata puskuensis subsp. n. Figs. 1-4-M element: 1-lateral view, Cn 5355, sample $M-226 ; 2$, 4-aboral and lateral views, Cn 5356, sample M-226; 3-lateral view, Cn 5279, sample Pk-2(79). Figs. 5, 9, 12-Sc element: 5, 12-lateral and aboral views, $C_{n}$ 5367, sample $M-226$; 9-lateral view, $C_{n}$ 5291, sample M-226. Figs. 6-8-Sb element: 6, 7-posterior and aboral views, $\mathrm{Cn} 5304$, sample M-226; 8-posterior view, Cn 5392, sample M-226. Figs. 10, 11, 13-Sa element: 10-posterior view, Cn 5399, sample $M-226 ; 11,13$-posterior and aboral views, Cn 5309, sample M-226.

\section{PLATE III}

Magnification $\times 100$.

Figs. 1, 2, 5, 6, 10, 11-Oulodus? cf. kentuckyensis. 1-Pa element, lateral view, Cn $5438 ; 2-\mathrm{Pb}$ element, lateral view, $\mathrm{Cn} 5441 ; 5-M$ element, lateral view, $\mathrm{Cn} \mathrm{7741}$; 6 -Sc element, lateral view, Cn 5447; 10 - Sa element, posterior view, Cn 5454;11-Sb element, posterior view, Cn 5450. Figs. 1, 2, 6, 10, and 11 from the Pusku section, sample M-226; fig. 5 from the Kallasto section, sample $M-250$.

Figs. 3, 4, 7-9-Gen. et sp.n. 1. 3-Sb(?) element, posterior view, Cn 5458; 4-Sa element, posterior view, $\mathrm{Cn} 5500 ; 7-\mathrm{P}$ (?) element, posterior view, $\mathrm{Cn} 5457 ; 8-\mathrm{M}$ element, inner lateral view, $\mathrm{Cn} 5493 ; 9-\mathrm{Pa}($ ?) element, outer lateral view, Cn 5456. Figs. 3,7 , and 9 from the Pusku section, sample M-226; fig. 4 from the Vinguta section, sample M-523; fig. 8 from the Mõisamaa section, sample $M s-6$. 
PLATE I

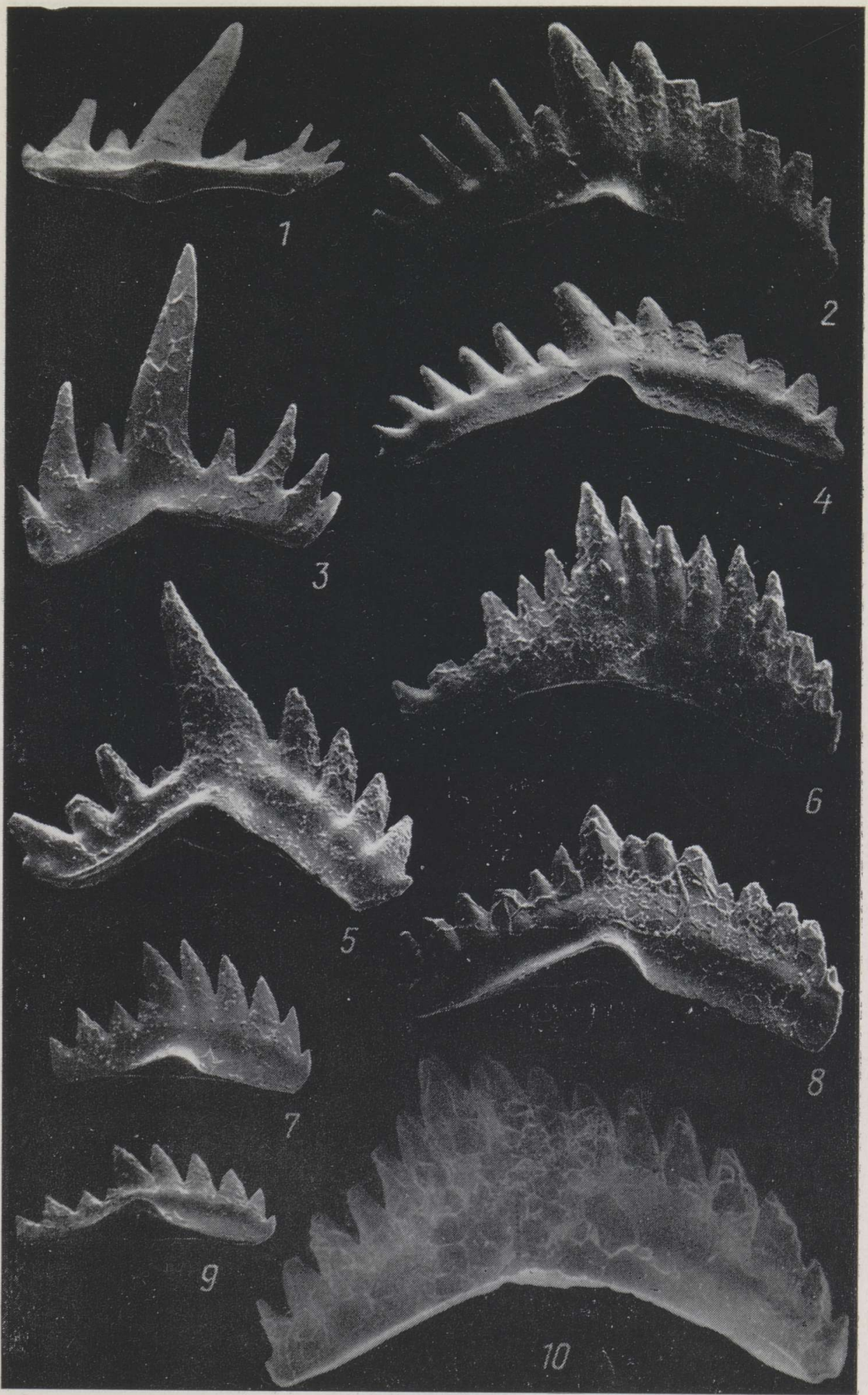




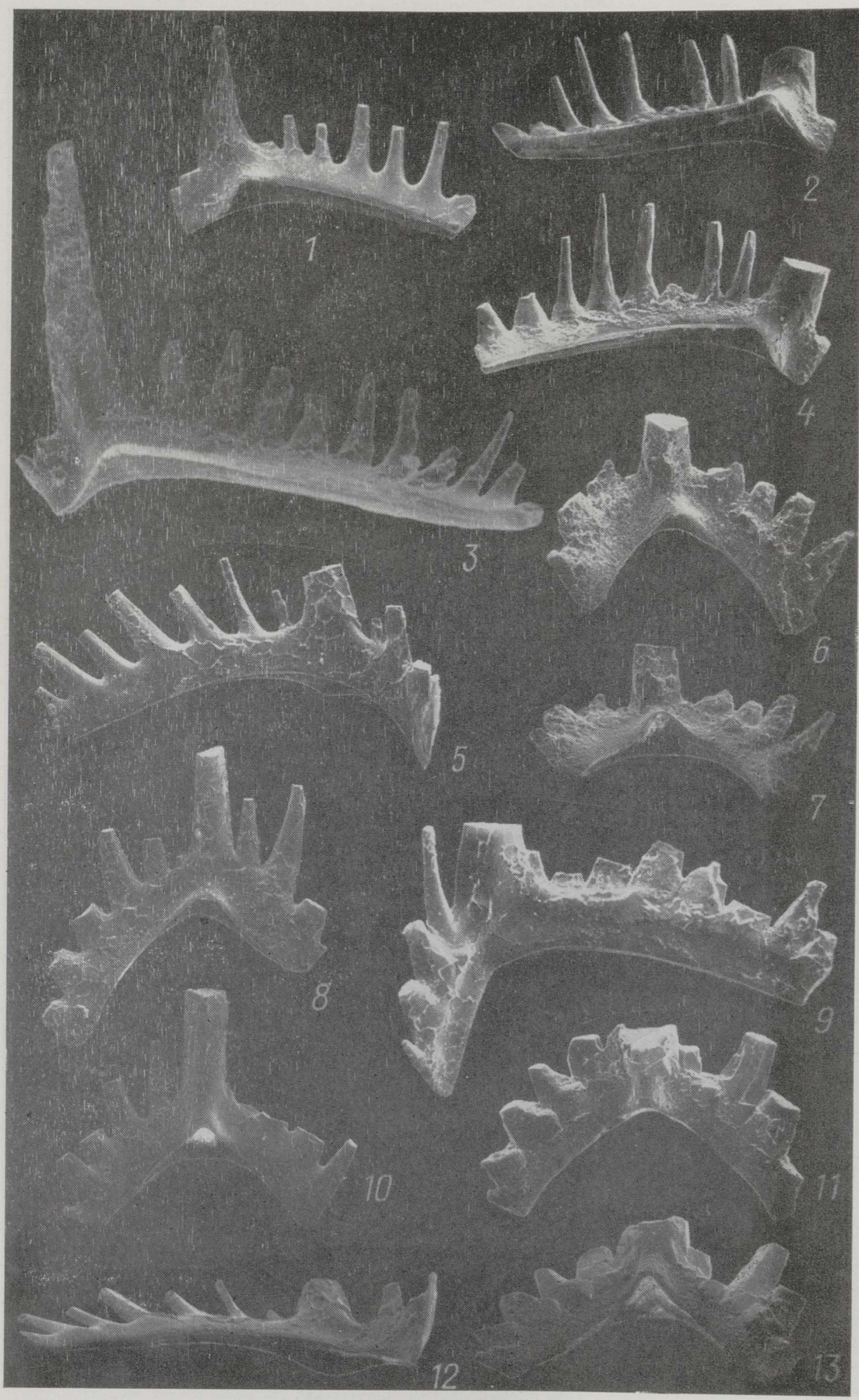




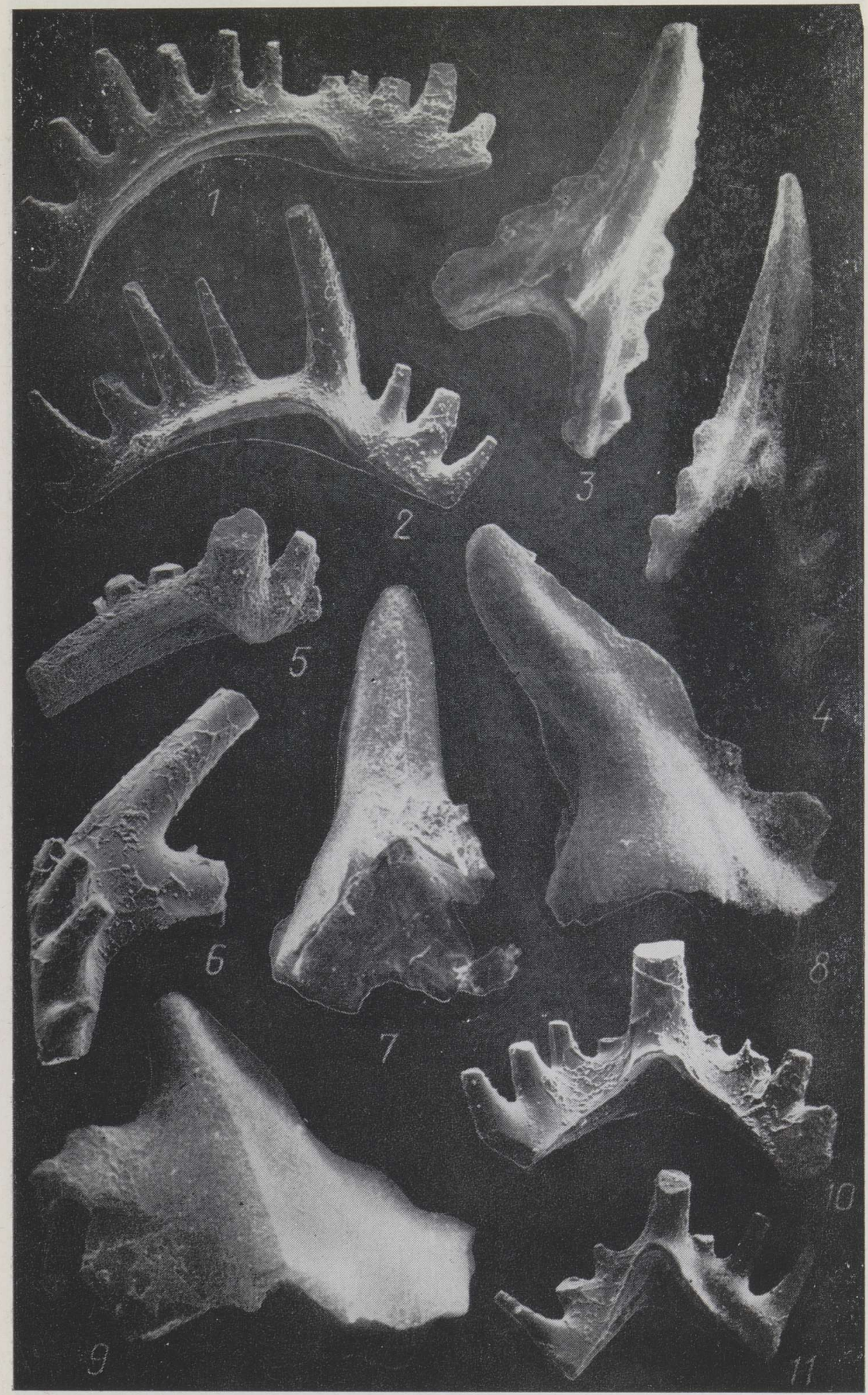




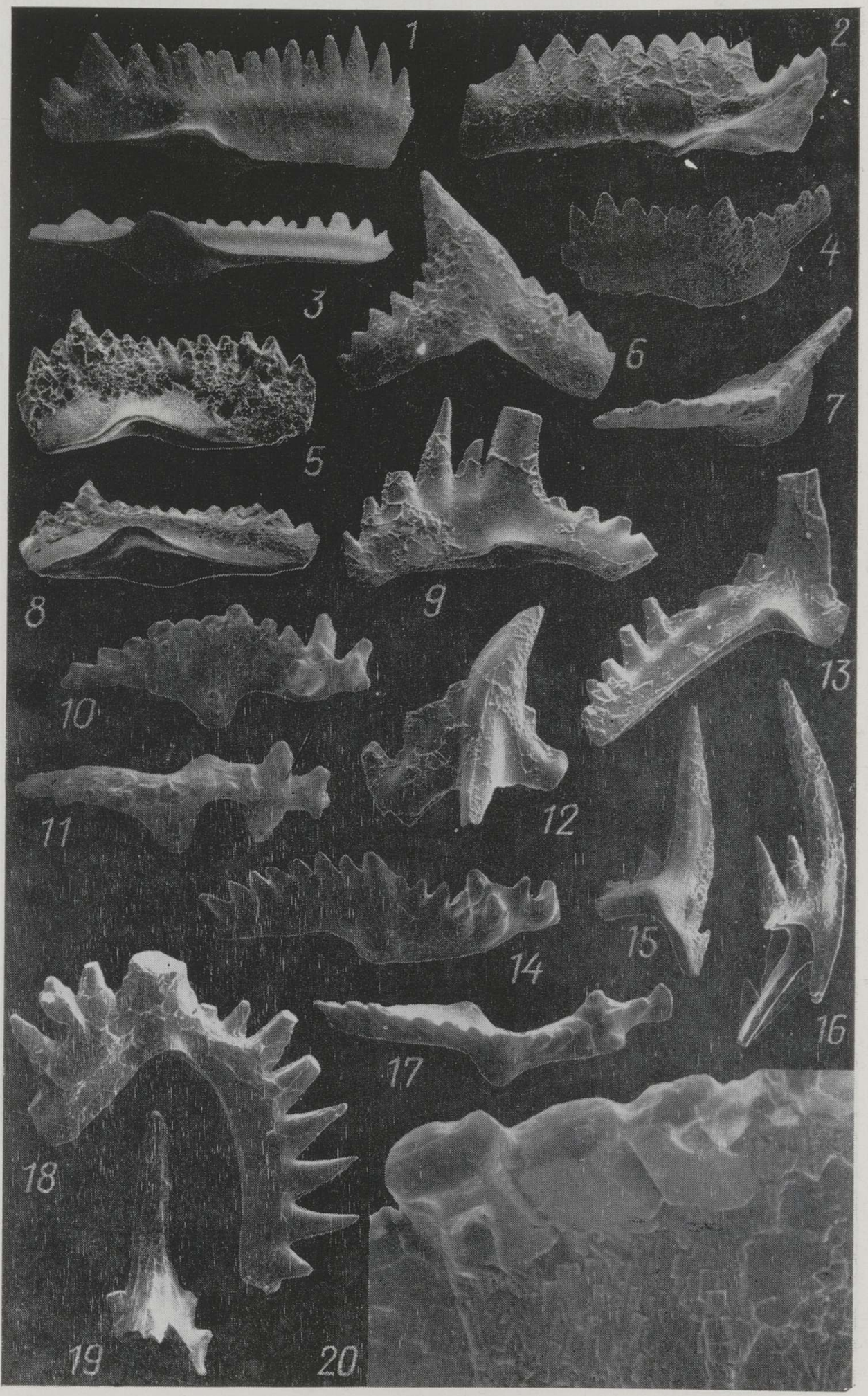



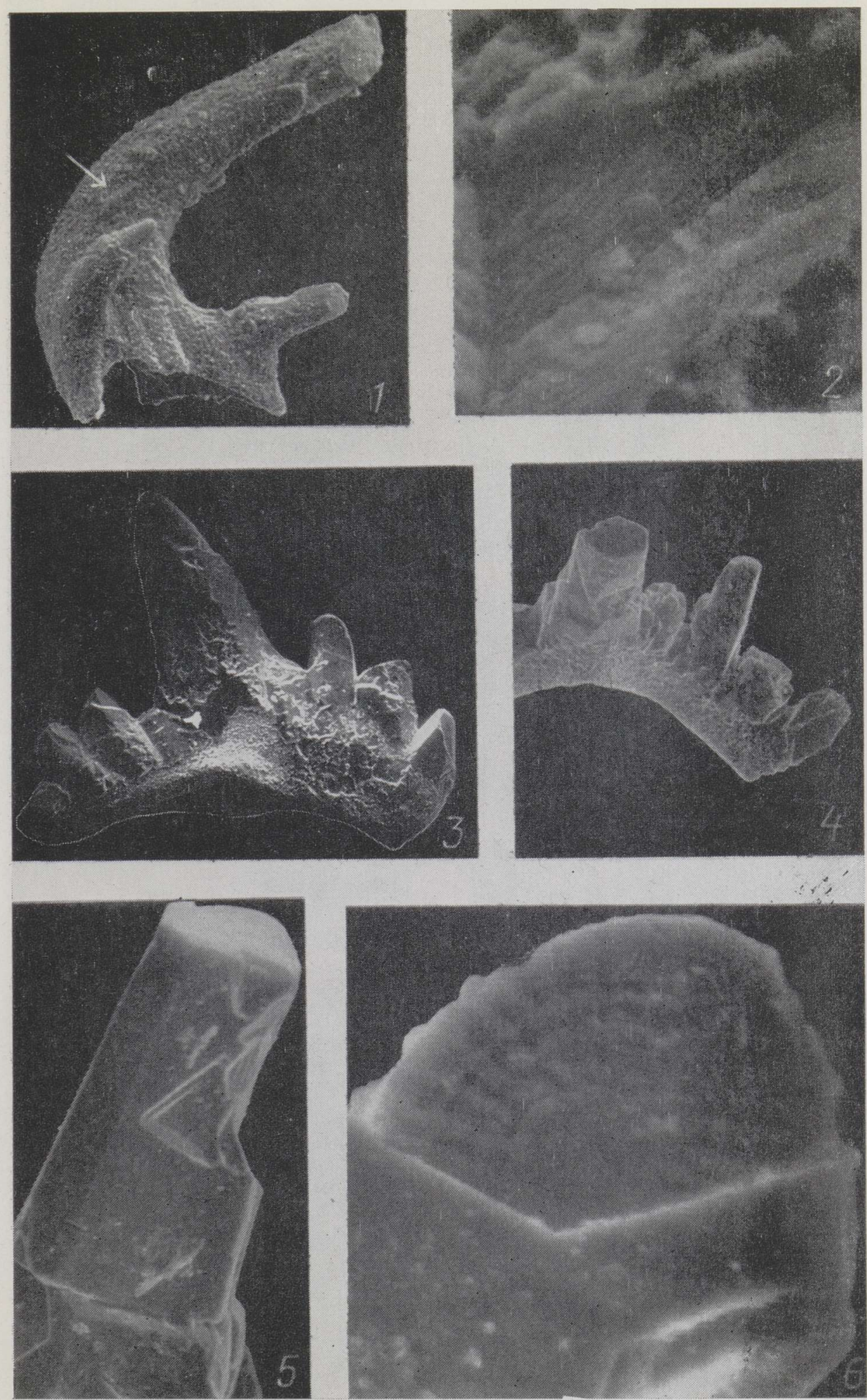

$\therefore \therefore$

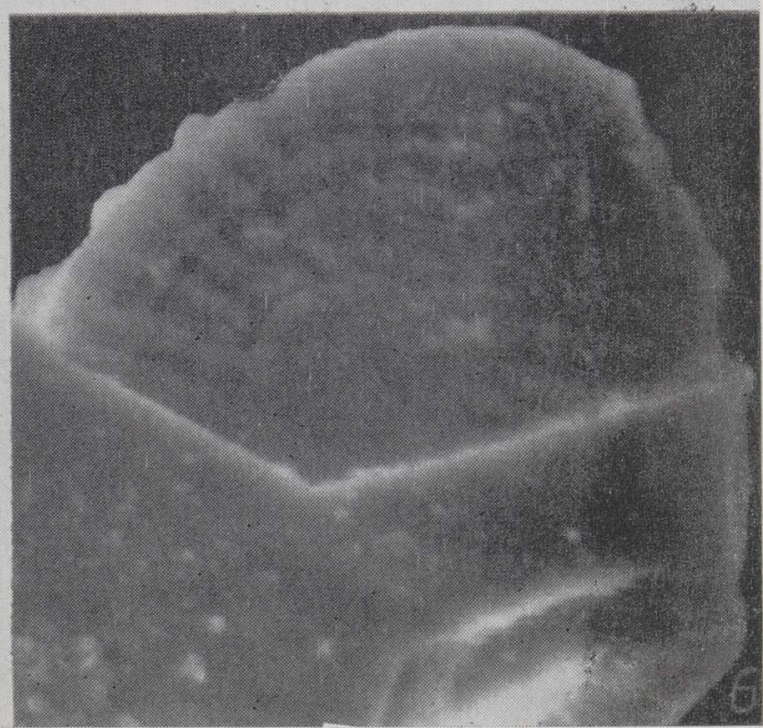



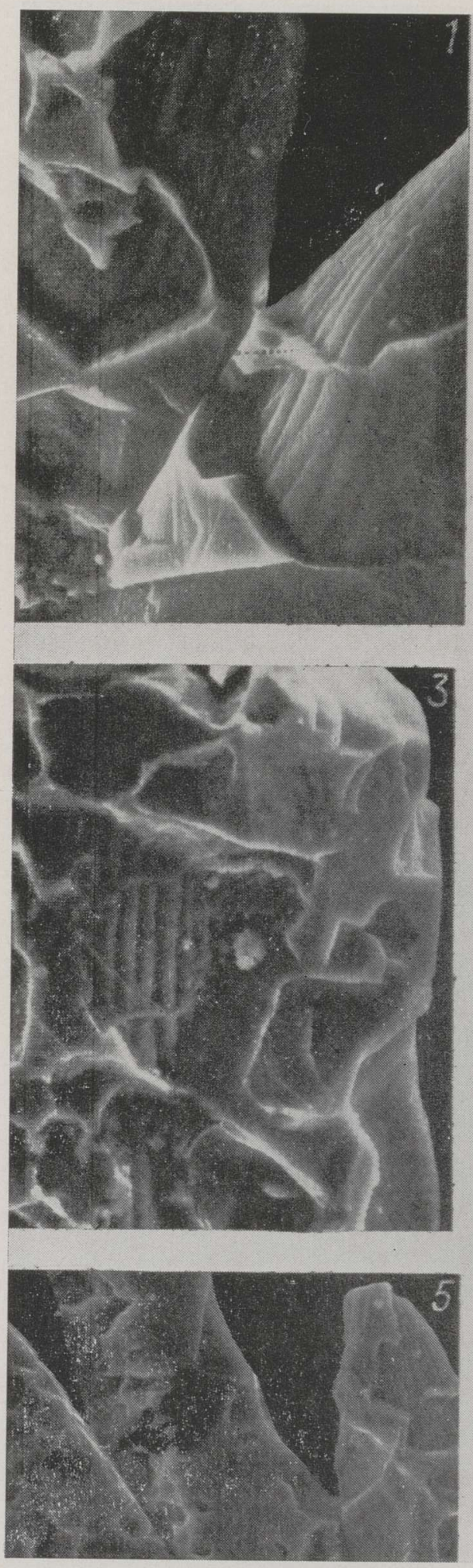
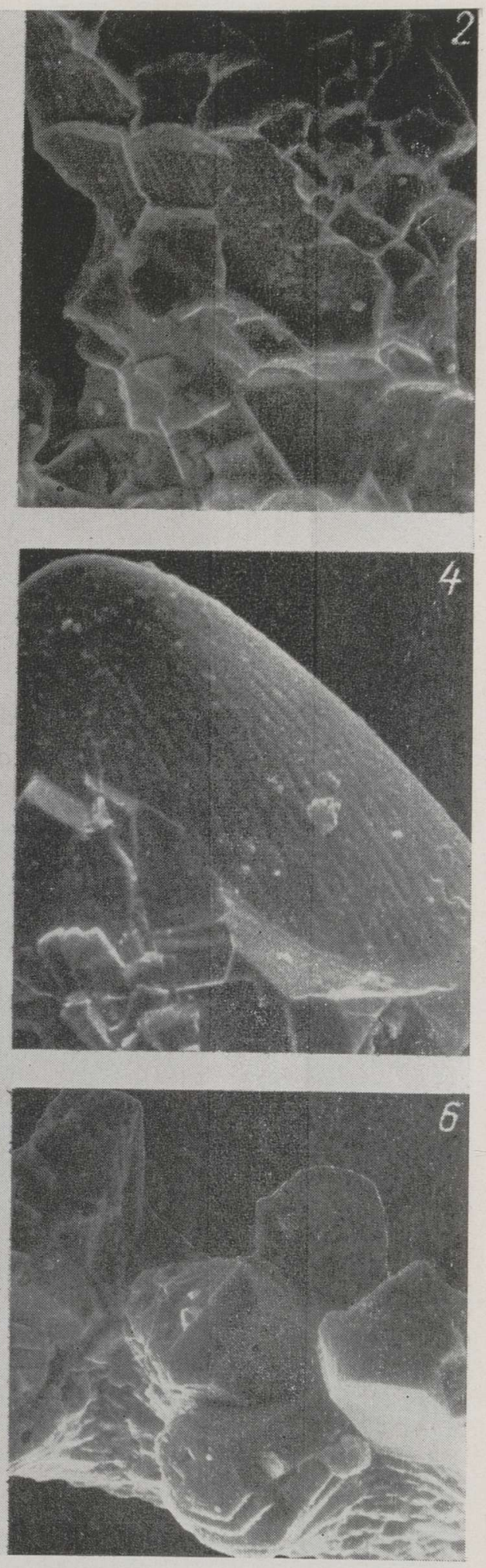
The Sb element (Pl. II, figs. 6-8) has a tall posteriorly curved cusp and downward directed lateral processes of unequal length forming an asymmetrical angular arch. The shorter process is almost straight, the longer one is curved downwards. The denticles on the processes have sharp edges and are almost discrete. The shallow basal cavity is expanded backwards beneath the cusp and continues as a groove on the aboral surfaces of the processes.

The Sa element (P1. II, figs. 10, 11, 13) has a tall posteriorly curved and slightly twisted cusp with sharp edges. The lateral processes of unequal length are curved steeply down and form a symmetrical arch.

\section{PLATE IV}

Figs. $1-19 \times 100$; fig. $20 \times 430$.

Figs. 1, 3-Ozarkodina sp. aff. O. sp.n. A Aldridge and Idris, 1982. Lateral and aboral views, Cn 5533, Rohuküla section, sample Rh-6(81).

Figs. 2, 4, 6, 7, 9, 13, 18-Kockelella manitoulinensis. Figs. 2, 4, 7-Pa element: 2-inner lateral view, Cn 5421; 4, 7-outer lateral and upper views, Cn 7714. Fig. 6-Pb element, outer lateral view, Cn 5427. Fig. 9-Sc element, inner lateral view, Cn 5432. Fig. 13-M element, inner lateral view, $\mathrm{Cn}$ 5430. Fig. 18-Sb element, posterior view, Cn 5434. Figs. 2, 6, 9, 13, and 18 from the Pusku section, sample $M-226$; figs. 4 and 7 from the Kallasto section, sample $M-250$.

Figs. 5, 8-Ozarkodina sp. n. B. Lateral and aboral views, Cn 5464, the Pusku section, sample $M-226$.

Figs. 10-12, 14-17, 19, 20-Icriognathus cornutus Männik. Figs. 10, 11, 14, 17-Pa element: 10, 11-inner lateral and upper views, Cn 5405; 14, 17-outer lateral and upper views, $\mathrm{Cn}$ 5401. Fig. $12-\mathrm{Pb}$ element, outer lateral view, $\mathrm{Cn}$ 5410. Fig. 15-M element, inner lateral view, Cn 5414. Fig. 16-Sb element, outer lateral view, Cn 5417. Fig. 19-Sa element, posterior view, Cn 5418. Fig. 20-a detail of the denticles of the $\mathrm{Pa}$ element, Cn 5405. All specimens from the Pusku section, sample M-226.

\section{PLATE V}

Figs. 1, 2-Rotundacodina? sp., the Mõisamaa section, sample Ms-4, Cn 5511: 1-lateral view, $\times 175 ; 2-$ a detail of the cusp of the element (marked by arrow in fig. 1) where the surface of the specimen is visible through the hole in the coating material.

Figs. 3-6-Ozarkodina excavata puskuensis subsp. n. Fig. 3-Pb element, Cn 5255, $\times$ 125. Fig. 4-Sa element, Cn 5394, $\times 170$. Figs, 5, 6-Sc element, Cn 5363: 5-upper part of the cusp, $\times 550 ; 6$-the internal structures of the cusp, visible on its upper surface, $\times 2250$. Specimens in figs. $3-6$ from the Pusku section, sample M-226.

\section{PLATE VI}

All specimens from the Pusku section.

Figs. 1-5-Ozarkodina excavata puskuensis subsp. n. Fig. 1-Pb element, a detail of the denticles with the coating material, $\mathrm{Cn} 5333, \times 1150$, sample $\mathrm{Pk}-3 \mathrm{a}(81)$. Fig. $2-\mathrm{Pb}$ element, a detail of the denticle with the coating material, Cn 5268, $\times 700$, sample Pk-3(79). Fig. $3-M$ element, a detail of the cusp, totally covered with the coating material. The conodont surface is visible only through a small hole in the coating, Cn 5276, $\times 1250$, sample $M-226$. Fig. $4-\mathrm{Pb}$ element, a detail of the top of the cusp with the contact of the coating material and the conodont surface, Cn 5255, $\times 900$, sample $M-226$. Fig. 5-Pa element, a detail of the denticles almost totally covered with the coating material, Cn 5250, $\times 650$, sample Pk-3(79). Fig. 6-Icriognathus cornutus, $\mathrm{Pa}$ element, a detail of the anterior process, where the denticles are totally covered with the coating material forming six-faced crystals, Cn $5404, \times 750$, sample M-226. 
The processes bear almost discrete, slightly compressed in the plane of the processes posteriorly curved denticles. They have sharp edges and are separated by narrow U-shaped gaps. The largest denticles are situated on the distal parts of the processes. The almost shallow basal cavity is considerably expanded posteriorly beneath the cusp and continues as a narrow groove on the aboral surfaces of the processes.

Variation. The described elements, particularly the shape of their denticulation, are highly variable. The denticles of the juvenile $\mathrm{Pb}, \mathrm{M}, \mathrm{Sc}, \mathrm{Sb}$, and Sa elements (Pl. I, figs. 1, 3, 7, 9; P1. II, figs. 1, 2, 4, 5, 8, 10, 12) are separated by wider (U-shaped) gaps than those on the larger ones (P1. I, figs. 2, 4, 5, 6, 8, 10; P1. II, figs. 3, 6, 7, 9, 11, 13).

The arching of the blade of the $\mathrm{Pa}$ element increases during the growth varying from an almost straight blade in the juvenile specimens (P1. I, figs. 7,9 ) to a greatly arched one in adults (Pl. I, figs. 6, 10).

Remarks. O. protexcavata described by Cooper (1975) from the Brassfield Limestone of southern Ohio seems to be morphologically the closest to O. e. puskuensis. As the information available (Cooper, 1975: 1006, P1. 3, figs. $1-6$ ) suggests the main differences between these taxa lie in $O$. protexcavata having more compressed elements and wider, more completely fused denticles than O. e. puskuensis.

According to Cooper, the $\mathrm{Pa}$ and $\mathrm{Pb}$ elements of $O$. protexcavata are almost similar and, accordingly, correspond to Ozarkodina sp. n. A s. f. and Ozarkodina sp. n. B s. f. of Pollock et al. (1970: Pl. 113, figs. 5-8 and $9-11)$.

Elements similar to Ozarkodina sp. n. A s. f. and Ozarkodina sp. n. B s. f. (Pollock et al., 1970) occur abundantly in the Estonian material and they are here considered to represent different types of the $\mathrm{Pa}$ element of $O$. e. puskuensis. The differences between these elements are probably caused by the intraspecific variation.

The $\mathrm{Pb}$ position in the $O$. e. puskuensis apparatus is thought to be occupied by a typical ozarkodiniform element (Pl. I, figs. 1, 3, 5), which is quite similar to the specimen illustrated by Cooper (1975: P1. 3, fig. 5) as an $M$ element of $O$. protexcavata. However, this is evidently not an $M$ but a $\mathrm{Pb}$ (ozarkodiniform) element with a broken posterior process. The $\mathrm{Pb}$ element of $\mathrm{O}$. e. puskuensis is completely different from Ozarkodina sp. n. B s. f. of Pollock et al. (1970: Pl. 113, figs. 9-11).

Occurrence. The upper Rhuddanian and Aeronian: the uppermost part of the Tamsalu Formation (the Juuru Regional Stage) and the Raikküla Formation (the Raikküla Regional Stage) in Estonia.

\begin{tabular}{lrrrrrr} 
Material (specimens). & $\mathrm{Pa}$ & $\mathrm{Pb}$ & $\mathrm{M}$ & $\mathrm{Sc}$ & $\mathrm{Sb}$ & $\mathrm{Sa}$ \\
From the Pusku section: & 1100 & 350 & 400 & 750 & 300 & 170 \\
From other sections (36): & 412 & 134 & 85 & 158 & 119 & 52 \\
\hline Total: & 1512 & 484 & 485 & 908 & 419 & 222
\end{tabular}

\section{ACKNOWLEDGEMENTS}

I am grateful to D. Kaljo and $\mathrm{H}$. Nestor for their advice and critical reading of the manuscript, to $\mathrm{U}$. Moldov and $\mathrm{E}$. Grünberg for the photos, to $K$. Ronk for drawing the figures, and to $\dot{A}$. Noor for the linguistic improvements. 


\title{
REFERENCES
}

Aldridge, R. J. 1972. Llandovery conodonts from the Welsh Borderland. - Bull. Brit. Mus. Nat. Hist. (Geol.), 22, 2, 125-231.

Aldridge, R. J. 1975. The stratigraphic distribution of conodonts in the British Silurian. - J. Geol. Soc., 131, 607-618.

Armstrong, H. A. 1990. Conodonts from the Upper Ordovician-Lower Silurian carbonate platform of North Greenland. - Grønlands Geologiske Undersøgelse, Bull. 159.

Cooper, B. J. 1975. Multielement conodonts from the Brassfield Limestone (Silurian) of southern Ohio. - J. Paleont., 49, 6, 984-1008.

Einasto, R., Männik, P. 1991. Peatus 2.4. Pusku e. Ungru-Sepaküla paemurd. - In: Puura, V., Kalm, V., Puura, I. (eds.). Eesti geoloogiline ehitus ja maavarad: ekskursioonijuht. Eesti Geoloogia Selts, Tallinn, 49-51.

Männik, P. 1992. A new conodont from the lower Llandovery of Estonia. - Proc. Estonian Acad. Sci. Geol., 41, 2, 54-62.

Männik, P., Viira, V. 1990. Conodonts. - In: Kaljo, D., Nestor, H. (eds.). Field Meeting Estonia 1990. Tallinn, 84-89.

Pollock, C. A., Rexroad, C. B., Nicoll, R. S. 1970. Lower Silurian conodonts from northern Michigan and Ontario. - J. Paleont., 44, 4, 743-746.

Walliser, O. H. 1964. Conodonten des Silurs. - Abh. hess. Landesamt. Bodenforsch., 41.

Аалоэ А., Нестор Х. 1977. Биогермная фация в юуруском горизонте (нижний лландовери) в Северо-Западной Эстонии. - In: Қальо Д. (ed.). Фации и фауна силура Приббалтики. АН ЭССР, Таллинн, $71-88$.

Қальо Д. 1967. О возрасте нижних горизонтов силура Эстонии. - Изв. АН ЭССР. Хим. Геол., 16, 1, 62-68.

Нестор В. 1980. Новые виды хитинозой из нижнего лландовери Эстонии. - Изв. АН ЭССР. Геол., 29, 3, 98-107.

\section{KONODONTE PUSKU LÄBILÕIKEST, ALAM-LLANDOVERY, EESTI}

\author{
Peep MANNIK
}

Artiklis on toodud Pusku läbilõike lühike litoloogiline ja faunistiline (konodondid) iseloomustus. Uue konodontide alamliigina on kirjeldatud Ozarkodina excavata puskuensis't.

\section{КОНОДОНТЫ ИЗ РАЗРЕЗА ПУСКУ, НИЖНИЙ ЛЛАНДОВЕРИ, ЭСТОНИЯ}

\section{Пээп МЯННИК}

Из разреза Пуску, представленного разнотипными известняками мелководного генезиса, описана разнообразная конодонтовая фауна, в которой доминируют элементы типа Ozarkodina excavata. Последние описаны как новый подвид названного вида - O. e. puskuensis ssp. $\mathrm{n}$.

Наряду с O. e. puskuensis в разрезе Пуску определены Kockelella manitoulinensis, Ozarkodina sp. (aff. O. sp. n. A Aldridge et Idris, 1982), Oulodus? cf. kentuckyensis, Icriognathus cornutus, Panderodus spp., Ozarkodina sp.n. B и Gen. et sp.n. 1, являющиеся характерными для райккюлаского поризонта Әстонии и позволяющие скоррелировать изученный разрез с верхами рудданиана. 